Agric. Biol. Chem., 42 (3), 613 621, 1978

\title{
Biodegradative Threonine Deaminase from Proteus morganii
}

\author{
Hidehiko Kumagal, Tetsujiro Nishimura* and Hideaki Yamada** \\ Department of Food Science and Technology, Faculty of Agriculture, \\ Kyoto University, Kyoto 606, Japan \\ *Research Institute for Food Science, Kyoto University, Kyoto, Uji 611, Japan \\ **Department of Agricultural Chemistry, Faculty of Agriculture, \\ Kyoto University, Kyoto 606, Japan
}

Received October 31, 1977

\begin{abstract}
Biodegradative threonine deaminase was purified and crystallized from cells of Proteus morgamii grown aerobically in the medium containing high concentrations of amino acids. The enzyme was homogeneous by the criteria of ultracentrifugation and SDS disc gel electrophoresis. The molecular weight of the enzyme was determined to be approximately 120,000 by the gel filtration method. The molecular weight of subunit of the enzyme was estimated to be 32,000 by SDS disc gel electrophoresis. The enzyme seems to have a tetrameric structure consisting of identical subunits. The enzyme has a marked yellow color with an absorption maximum at $415 \mathrm{~nm}$ and contains 4 moles of pyridoxal phosphate per mole of enzyme protein. The threonine deaminase was activated by AMP and ADP. It catalyzed the deamination of $\mathrm{L}$-threonine, $\mathrm{L}$-serine and $\beta$-chloro-L-alanine. The optimal $\mathrm{pH}$ was about 9.0 in the absence of AMP. In the presence of $1 \mathrm{mM}$ AMP, the optimal pH became in a range between 8.0 and 9.5. The enzyme was not inhibited by $\mathrm{L}$-isoleucine. Its $\mathrm{Km}$ values for L-threonine were found to be $1.5 \mathrm{~mm}$ and $24 \mathrm{~mm}$, in the presence and absence of $1 \mathrm{~mm}$ AMP, respectively. The $K a$ value for AMP was found to be $0.55 \mathrm{~mm}$ at the threonine concentration of $5 \mathrm{mM}$. However, the value was varied depending on the concentration of $\mathrm{L}$-threonine.
\end{abstract}

The existence of two distinctly different $\mathrm{L}$ threonine deaminases ( $\mathrm{L}$-threonine hydro-lyase (deaminating) EC 4.2.1.16), biosynthetic and biodegradative ones, has been reported in $E$. coli. Both enzymes contain pyridoxal phosphate as a cofactor and catalyze $\alpha, \beta$ elimination reaction of $\mathrm{L}$-threonine to generate a-ketobutyrate and ammonia. Biosynthetic threonine deaminase participates in the biosynthesis of L-isoleucine from L-threonine and is characterized by end product inhibition by L-isoleucine." On the other hand, biodegradative one participates in the catabolism of $\mathrm{L}$ threonine and is characterized by marked activation by AMP. ${ }^{2)}$ In the bacterium, the biosynthetic one is formed in the cells constitutively, while the biodegradative threonine deaminase is formed inducibly under anaerobic conditions.

In our recent studies on threonine metabolism by bacteria, it was found that Proteus morganii produced both biosynthetic and bio- degradative threonine deaminases simultaneously, under aerobic culture conditions. ${ }^{31}$ This paper will report the purification, crystallization and some properties of biodegradative threonine deaminase from $P$. morganii.

\section{MATERIALS AND METHODS}

Materials. L-Threonine was kindly provided by Ajinomoto Company, Ltd., Tokyo, and pyridoxal phosphate was by Dainippon Pharmaceutical Company, Ltd., Osaka. The other chemicals used were best available commercial products.

Microorganism. Proteus morganii (Faculty of Agriculture, Kyoto University, AKU 0084) was chosen for the enzyme source, since the bacterium had shown the highest threonine deaminase activity of all the 35 bacteria subjected to the screening.

Culturing procedures. The medium consisted of $0.5 \%$ polypepton, $0.5 \%$ meat extract, $0.65 \%$ yeast extract, $0.2 \% \mathrm{NaCl}$ and $0.3 \%$ succinic acid in tap water. The $\mathrm{pH}$ of the medium was adjusted to 7.0 .

The strain was inoculated into a seed culture, $5 \mathrm{ml}$ of 
the medium in a test tube, which was incubated at $30^{\circ} \mathrm{C}$ for $24 \mathrm{hr}$ with reciprocal shaking. The seed culture was then inoculated into a subculture, $500 \mathrm{ml}$ of the same medium in a 2-liter shaking flask. After incubated at $30^{\circ} \mathrm{C}$ for $24 \mathrm{hr}$ with reciprocal shaking, the subculture was inoculated into a 50-liter fermentor jar (MSJ-U501 Marubishi Co. Ltd., Tokyo, Japan) containing 40 liters of the same medium, which was then incubated at $30^{\circ} \mathrm{C}$ for $16 \mathrm{hr}$ with aeration ( 40 liters $/ \mathrm{hr}$ ). Approximately $9 \mathrm{~g}$ of cells (wet weight) were obtained per liter of the medium.

Enzyme assay. The activity of threonine deaminase was determined spectrophotometrically by measuring the amount of $\alpha$-ketobutyrate formed from L-threonine. The standard assay system contained $10 \mu$ moles of $\mathrm{L}$ threonine, $0.4 \mu$ mole of $\mathrm{NH}_{4} \mathrm{OH}-\mathrm{NH}_{4} \mathrm{Cl}$ buffer, $\mathrm{pH}$ 9.5 , and the enzyme in a total volume of $4.0 \mathrm{ml}$, unless otherwise specified. The reaction mixture was incubated at $30^{\circ} \mathrm{C}$ for $20 \mathrm{~min}$ and the reaction was then terminated by the addition of $1.0 \mathrm{ml}$ of $30 \%$ trichloroacetic acid. The amount of the keto acid formed was determined as the 2,4-dinitrophenylhydrazone at 450 nm by the method of Friedemann and Haugen, $\left.{ }^{4}\right)$ or as $\mathrm{N}$-metylbenzothiazolonehydrazide at $320 \mathrm{~nm}$ by the modified method of Soda. (MBTH method). ${ }^{5 !}$ One unit of the enzyme activity was defined as the amount of enzyme producing $1 \mu$ mole of $\alpha$-ketobutyrate per minute under the standard assay conditions. Specific activity was expressed as units per $\mathrm{mg}$ of protein.

Protein determination. Protein concentration was determined spectrophotometrically by measuring the absorbance at $280 \mathrm{~nm}$. An E value of 12.7 for $10 \mathrm{mg}$ per $\mathrm{ml}$ and for $1 \mathrm{~cm}$ light path, which was used throughout, was obtained by absorbance and dry weight determinations.

Spectrophotometric determination. Spectrophotometric determinations were carried out with a Beckman Spectra-20 spectrophotometer. Absorption spectra of the enzymes were measured with a Shimazu Multipurpose Recording Spectrophotometer MPS-5000.

Ultracentifugal analysis. Sedimentation velocity experiments were carried out with a Hitachi Analytical Ultracentrifuge operated at $51,200 \mathrm{rpm}$ at $20^{\circ} \mathrm{C}$. Diffusion coefficient was measured with the same apparatus operated at $9690 \mathrm{rpm}$ at $20^{\circ} \mathrm{C}$, with the boundary condition at the meniscus in a sector shaped centrifuge cell. ${ }^{e}$ )

Electrophoresis. Disc gel electrophoresis was carried out with acrylamide gel in tris (hydroxymethyl) aminomethane-glycine buffer, $\mathrm{pH} 8.3$, according to Ornstein $^{7}$ and Davis. ${ }^{81}$ The disc gel electrophoresis in $0.1 \%$ SDS was carried out using the method of Weber and Osborn. ${ }^{\theta}$ After the run the gel was stained with $0.25 \%$ Coomassie brilliant blue, destained with dif- fusion, and stored in $7.5 \%$ acetic acid and $5 \%$ methanol.

Determination of pyridoxal phosphate. Pyridoxal 5 '-monophosphate was determined with a Hitachi Fluorescence Spectrophotometer MPF-4 by the fluorometric method of Adams. ${ }^{10}$

\section{RESULTS}

\section{Purification and crystallization of the enzyme}

All subsequent extraction and purification procedures were carried out at $0 \sim 5^{\circ} \mathrm{C}$, unless otherwise specified.

Step 1: Preparation of cell extract. A total of $720 \mathrm{~g}$ (wet weight) of cells were suspended with 3 liters of a $0.05 \mathrm{M}$ dilution buffer. This buffer consisted of various concentrations of $\mathrm{K}_{2} \mathrm{HPO}_{4}-\mathrm{KH}_{2} \mathrm{PO}_{4}$ buffer, $\mathrm{pH} 7.0,1 \mathrm{~mm} \mathrm{2-}$ mercaptoethanol, $0.01 \mathrm{~mm}$ EDTA and $0.01 \mathrm{~mm}$ pyridoxal phosphate. The suspended cells were disrupted with a Dyno-mill KDL (Willy A Bachofen, Basel, Switzerland).

Step 2: Streptomycin sulfate fractionation. Seven hundred milliliters of $10 \%$ solution of streptomycin sulfate was added to the cell suspension treated with Dyno-mill, under constant stirring. After $30 \mathrm{~min}$, the cell debris and precipitate formed were centrifuged off.

\section{Step 3: First ammonium sulfate fraction-} ation. The protein in the supernatant solution (4.2 liters) was precipitated by the addition of solid ammonium sulfate $(70 \%$ saturation). The precipitate was dissolved in 1.1 liters of the $0.05 \mathrm{M}$ dilution buffer described in step 1, and was dialyzed against 14 liters of the buffer for $36 \mathrm{hr}$. The buffer was changed 3 times at intervals of $9 \mathrm{hr}$. Insoluble materials formed during the dialysis were removed by centrifugation.

Step 4: DEAE-Sephadex column chromatography. The dialyzed solution (1.6liters) was then applied to a column of DEAE-Sephadex A-50 $(13.5 \times 45 \mathrm{~cm})$ equilibrated with the $0.05 \mathrm{M}$ dilution buffer. After washing the column with 20 liters of the $0.05 \mathrm{M}$ dilution buffer and subsequent 20 liters of the $0.1 \mathrm{M}$ dilution buffer, the elution of the enzyme was carried out with 


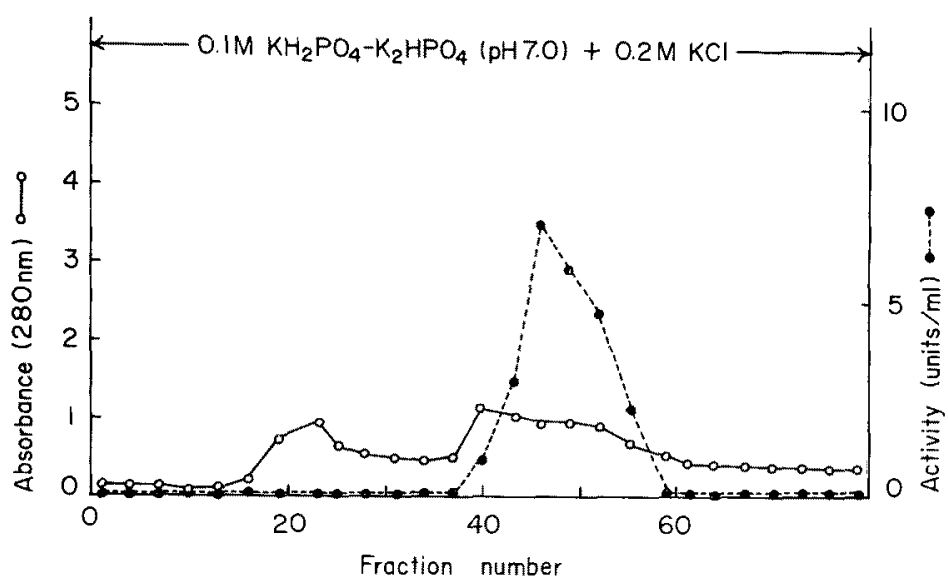

FIG. 1. Chromatography of Biodegaradative Threonine Deaminase on DEAE-Sephadex A-50. Crude enzyme solution (protein content, $51 \mathrm{~g}, 13,430$ units) was applied to a column $(13.5 \times 45 \mathrm{~cm})$, equilibrated with $0.05 \mathrm{M}$ potassium phosphate buffer, $\mathrm{pH} 7.0$, containing $1 \mathrm{~mm} 2$-mercaptoethanol, $0.01 \mathrm{~mm}$ EDTA and $0.01 \mathrm{~mm}$ pyridoxal phosphate. Open circles $(\mathrm{O}-\mathrm{O})$ represent the absorbance of protein at $280 \mathrm{~nm}$ and closed circles (---) represent the activity (units/ml).

$0.1 \mathrm{M}$ dilution buffer containing $0.2 \mathrm{M} \mathrm{KCl}$. The enzyme activity was recovered at the elution volume from 11.7 to 17.1 liters (Fig. 1). The protein was precipitated and dialyzed by the same way as described in step 3 .

Step 5: Second ammonium sulfate fractionation. The dialyzed enzyme solution was fractionated with ammonium sulfate at the intervals of $5 \%$ saturation. The threonine deaminase activity was separated into two parts by this procedure. One was precipitated between 30 and $45 \%$ saturation, and the other, between 45 and $60 \%$. These two enzymes were purified separately in subsequent steps. The purification and characterization of the latter enzyme will be described in this report.

Step 6: Hydroxylapatitie column chromatography. The enzyme solution $(25 \mathrm{ml})$ dialyzed against the $0.01 \mathrm{~m}$ dilution buffer without EDTA was placed on a hydroxylapatite column $(3.0 \times 6.0 \mathrm{~cm})$ equilibrated with the same buffer. After washing the column with $600 \mathrm{ml}$ of the same buffer and then with the $0.05 \mathrm{M}$ dilution buffer, the enzyme was eluted with $0.1 \mathrm{M}$ potassium phosphate buffer. The enzyme was recovered at the elution volume from $91 \mathrm{ml}$ to $169 \mathrm{ml}$ (Fig. 2).
Step 7: Sephadex G-200 gel filtration. The enzyme solution $(3.0 \mathrm{ml})$ was subjected to Sephadex G-200 gel filtration. The Sephadex was packed into a column $(2.5 \times 100 \mathrm{~cm})$ and equilibrated with the $0.05 \mathrm{M}$ dilution buffer. The enzyme was eluted with the same buffer and recovered at the elution volume from $210 \mathrm{ml}$ to $252 \mathrm{ml}$ (Fig. 3).

Step 8: Crystallization. To the concentrated enzyme solution $(1.0 \mathrm{ml})$, solid ammonium sulfate was gradually added until it became slightly turbid. The test tube containing the solution was then placed in an ice bath and was allowed to stand for several hours, until silky sheen was observed apparently. The test tube was then allowed to stand at $20^{\circ} \mathrm{C}$ overnight. Crystals were precipitated at the bottom of the test tube, and thin and rhombic crystals were observed under a microscope (Fig. 4). The color of the crystals was yellow.

The summary of the purification procedures is shown in Table I.

\section{Properties of the purified enzyme}

Homogeneity. The specific activity of enzyme achieved after the second crystallization was not altered upon further recrystalli- 


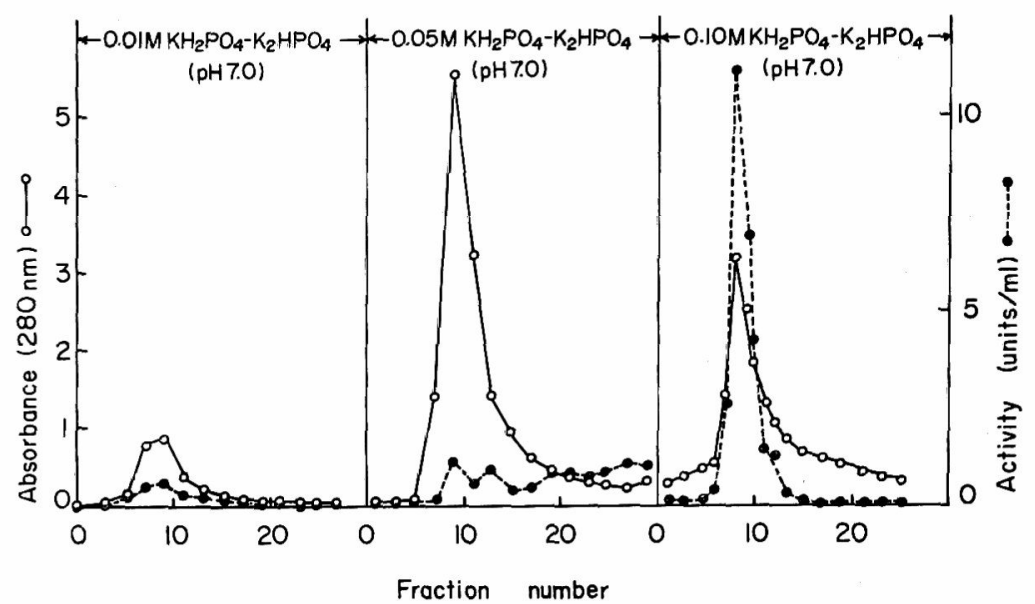

Fig. 2. Chromatography of the Partially Purified Biodegradative Threonine Deaminase on Hydroxylapatite.

Dialyzed enzyme solution (protein content, $882 \mathrm{mg}, 6,840$ units) was applied to a column ( $3.0 \times$ $6.0 \mathrm{~cm}$ ), equilibrated with $0.01 \mathrm{M}$ potassium phosphate buffer, $\mathrm{pH} 7.0$, containing $1 \mathrm{~mm} 2$-mercaptoethanol, $0.01 \mathrm{~mm}$ EDTA and $0.01 \mathrm{~mm}$ pyridoxal phosphate. Open circles $(\mathrm{O}-\mathrm{O})$ represent the

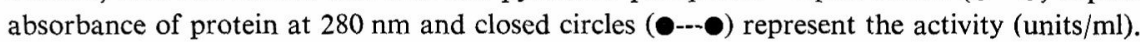

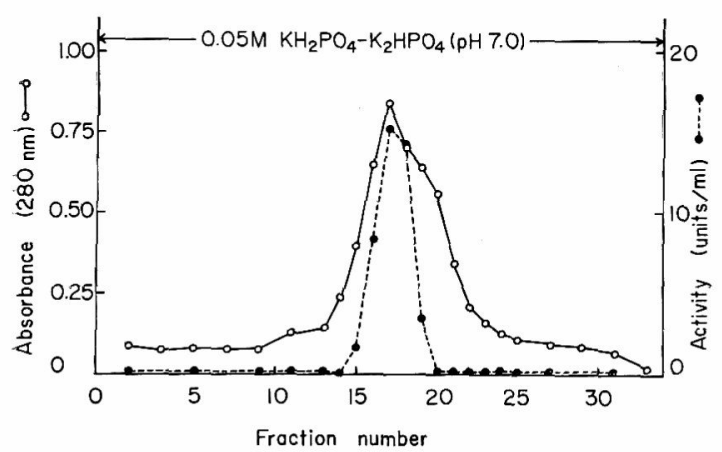

FIG. 3, Filtration of the Purified Biodegradative Threonine Deaminase on Sephadex G-200.

Purified enzyme solution (protein content, $66.3 \mathrm{mg}$, 1,800 units) was applied to a column $(2.5 \times 100 \mathrm{~cm})$, equilibrated with $0.05 \mathrm{M}$ potassium phosphate buffer, pH 7.0, containing $1 \mathrm{~mm} 2$-mercaptoethanol, $0.01 \mathrm{~mm}$ EDTA and $0.01 \mathrm{~mm}$ pyridoxal phosphate. Open circles $\left(\mathrm{O}_{-} \mathrm{O}\right)$ represent the absorbance of protein at $280 \mathrm{~nm}$ and closed circles (- represent the activity.

zation. The crystalline enzyme preparation migrated as a homogeneous entity when subjected to sedimentation experiments in an ultracentrifuge as shown in Fig. 5. A sedimentation coefficient $\left(s_{20, \mathrm{w}}^{0}\right)$ of $4.63 \mathrm{~S}$ and a diffusion coefficient $\left(D_{20, \mathrm{w}}\right)$ of $4.70 \times 10^{-7} \mathrm{~cm}^{2} /$

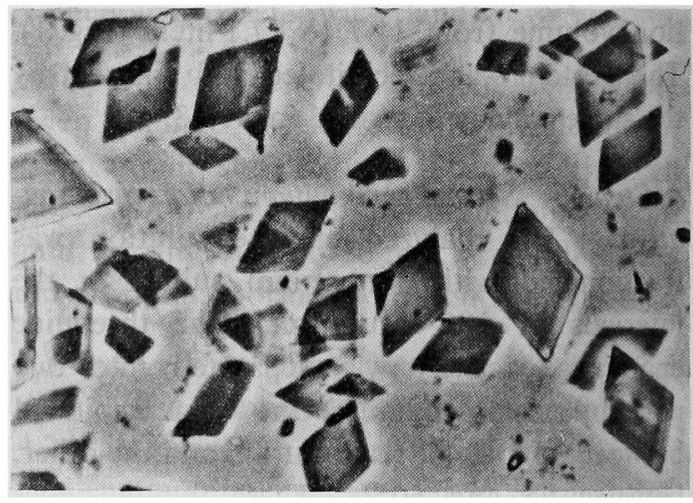

FIG. 4. Photomicrograph of Crystalline Biodegradative Threonine Deaminase from Proteus morganii.

sec were determined. Though the enzyme had shown wide and obscure band on disc gel electrophoresis carried out according to Ornstein $^{7)}$ and Davis, ${ }^{8)}$ it gave a clear single band on SDS disc gel electrophoresis (Fig. 6).

Molecular weight of the enzyme and the subunit. The molecular weight of the enzyme was determined by gel filtration through a Sephadex G-200 column. The result had shown that the enzyme has a molecular weight of approximately 120,000 (Fig. 7). The mole- 


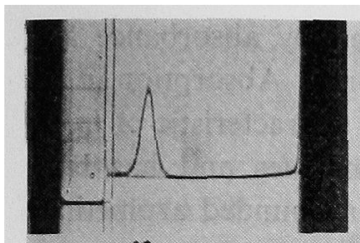

18

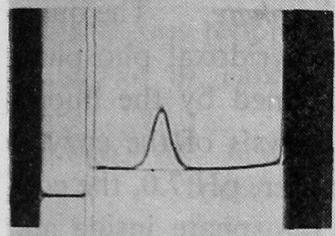

42

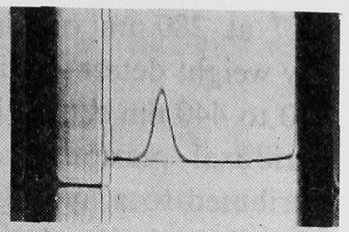

30

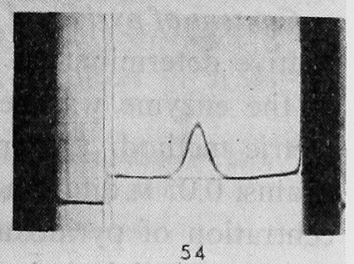

54

Fig. 5. Ultracentrifugal Patterns of Biodegradative Threonine Deaminase.

The protein concentration was $0.33 \%$ in $0.05 \mathrm{M}$ potassium phosphate buffer, $\mathrm{pH} 7.0$, containing $1 \mathrm{~mm}$ 2-mercaptoethanol, $0.01 \mathrm{mM}$ EDTA and $0.01 \mathrm{~mm}$ pyridoxal phosphate. The photographs were taken at intervals of $6 \mathrm{~min}$ after reaching $51,200 \mathrm{rpm}$ at $20^{\circ} \mathrm{C}$. These photographs were picked up at intervals of 12 min. Sedimentation is from left to right.

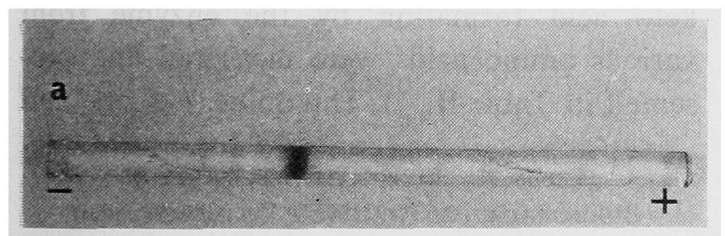

(a)

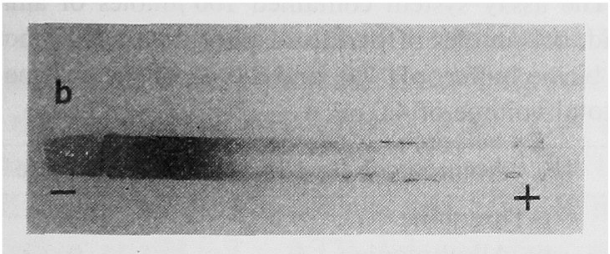

(b)

FIG. 6. Disc Gel Electrophoresis of Biodegradative Threonine Deaminase in the Presence (a) and Absence (b) of SDS.

(a). The SDS-treated enzyme $(13.2 \mu \mathrm{g})$ was subjected to the electrophoresis at a current of $8.0 \mathrm{~mA}$ for $6 \mathrm{hr}$ in $0.01 \mathrm{~m}$ sodium phosphate buffer, $\mathrm{pH} 7.0$, containing $0.1 \%$ SDS and $0.1 \%$ 2-mercaptoethanol. The direction of migration is from the cathode to the anode.

(b). Crystallized enzyme $(25 \mu \mathrm{g})$ was applied to the stacking gel and subjected to the electrophoresis at a current of $5.0 \mathrm{~mA}$ for $30 \mathrm{~min}$ in Tris-glycine buffer, $\mathrm{pH}$ 8.3. The direction of migration is from the cathode to the anode.

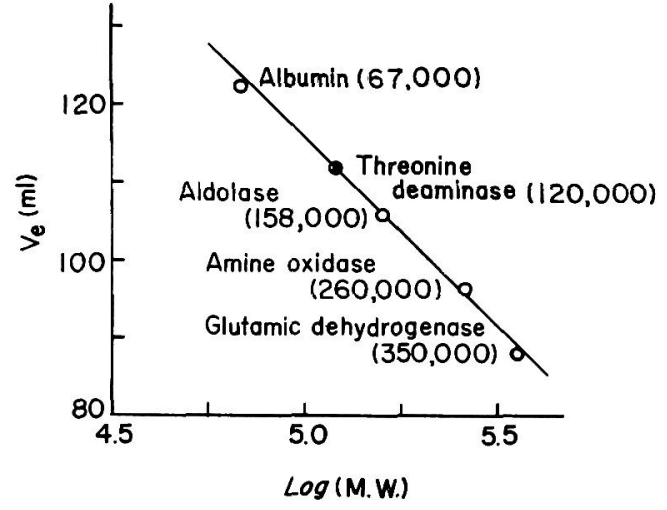

Fig. 7. Molecular Weight Determination of Biodegradative Threonine Deaminase by Sephadex G-200 Gel Filtration.

Albumin (bovine serum), aldolase (rabbit muscle), amine oxidase (Aspergillus niger) and glutamic dehydrogenase Type I (bovine liver) were used as marker proteins.

Table I. Purification of Biodegradative ThreONine DeAminase from P. morganii

\begin{tabular}{lcccc}
\hline Fraction & $\begin{array}{c}\text { Total } \\
\text { protein } \\
\text { (mg) }\end{array}$ & $\begin{array}{c}\text { Total } \\
\text { activity } \\
\text { (units) }\end{array}$ & $\begin{array}{c}\text { Specific } \\
\text { activity } \\
\text { (units/ } \\
\text { mg) }\end{array}$ & $\begin{array}{c}\text { Yield } \\
(\%)\end{array}$ \\
\hline $\begin{array}{l}\text { Cell extract } \\
\text { Streptomycin } \\
\quad \text { sulfate }\end{array}$ & 150,000 & 13,100 & 0.087 & 100 \\
$\begin{array}{l}\text { 1st Ammonium } \\
\quad \text { sulfate }\end{array}$ & 51,800 & 14,700 & 0.180 & 112 \\
$\begin{array}{l}\text { DEAE- } \\
\quad \text { Sephadex }\end{array}$ & 3,900 & 10,800 & 2.77 & 82 \\
$\begin{array}{l}\text { 2nd Ammonium } \\
\quad \text { sulfate }\end{array}$ & 882 & $\left.6,840^{a}\right)$ & 7.76 & 52 \\
$\begin{array}{l}\text { Hydroxylapatite } \\
\text { Sephadex }\end{array}$ & 66.3 & 1,800 & 27.1 & 14 \\
$\quad$ G-200 & 24.9 & 1,600 & 64.3 & 12 \\
Crystals & 11.2 & 925 & 82.6 & 7 \\
\hline
\end{tabular}

a) The units show only the enzyme activity precipitated $45 \sim 60 \%$ ammonium sulfate saturation. The enzyme activity preciptated $30 \sim 45 \%$ saturation had shown 4,250 units in total $(32.4 \%$ in yield) and was not included in the following purification steps.

cular weight of subunit of the enzyme was estimated to be approximately 32,000 by SDS disc gel electrophoresis (Fig. 8). These data show that the native enzyme has a tetrameric structure consisted of 4 identical subunits. 


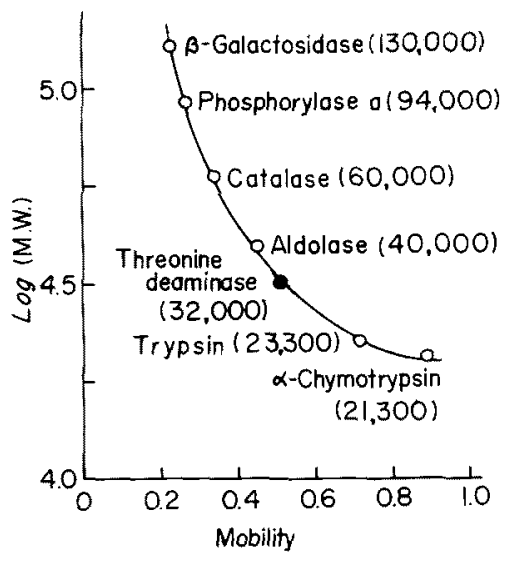

FIG. 8. Estimation of Molecular Weight of Subunit of Biodegradative Threonine Deaminase by SDS Disc Gel Electrophoresis.

The conditions of electrophoresis are the same as described in Fig. 6. $\beta$-Galactosidase $(E$, coli), phosphorylase a (rabbit muscle), catalase (bovine liver), aldolase (rabbit muscle), trypsin (bovin pancreas) and $\alpha$-chymotrypsin were used as marker proteins.

Absorption spectrum. The enzyme showed marked yellow color and its absorption spectrum at $\mathrm{pH} 7.0$ had a peak at the wave length of $415 \mathrm{~nm}$ besides the absorption at $280 \mathrm{~nm}$ (Fig. 9). The enzyme has an $E_{1 \% \mathrm{~m}}^{1 \%}$ value of

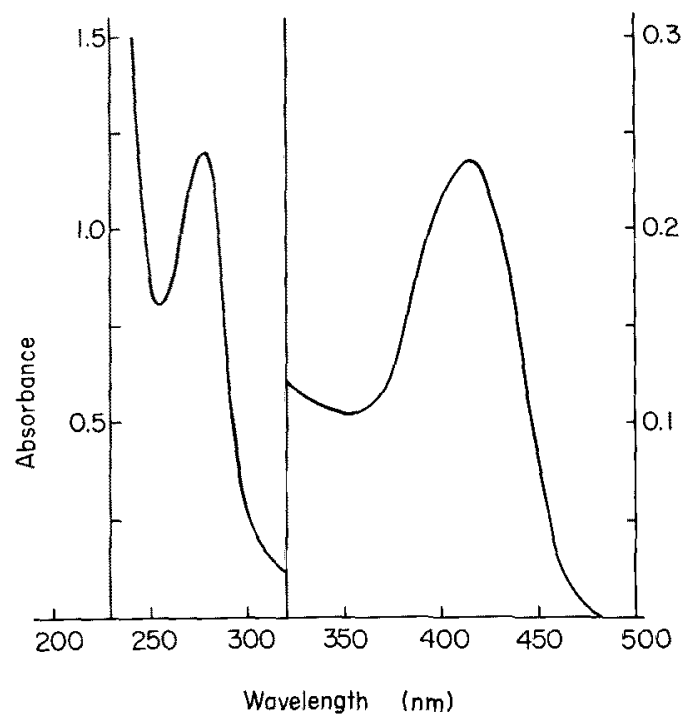

FIG. 9. Absorption Spectrum of Biodegradative Threonine Deaminase. The protein concentration was $1.1 \mathrm{mg}$ per $\mathrm{ml}$.
12.7 at $280 \mathrm{~nm}$ obtained by absorbance and dry weight determinations. Absorption in the 410 to $440 \mathrm{~nm}$ region is characteristic of many pyridoxal phosphate enzymes and has been attributed to a hydrogen-bounded azomethine of pyridoxal phosphate. ${ }^{11}$

Content of pyridoxal phosphate. The quantitative determination of pyridoxal phosphate in the enzyme was performed by the fluorometric method. After dialysis of the enzyme against $0.05 \mathrm{M}$ dilution buffer, $\mathrm{pH} 7.0$, the concentration of pyridoxal phosphate inside and outside the dialysis sac was determined by the method of Adams. ${ }^{10}$ A value of 3.4 moles per $120,000 \mathrm{~g}$ enzyme protein was observed, so the enzyme seems to contain about 4 moles of pyridoxal phosphate per mole of enzyme protein. This value of 4 moles of pyridoxal phosphate corresponds with the number of the subunit.

Substrate specificity. The relative rates of keto acid formation by the enzyme from various amino acids were measured and presented in Table II. L-Threonine, L-serine and

Table II. Substrate Specificity of

Biodegradative Threonine Deaminase from

$$
\text { P. morganii }
$$

The assay system contained $100 \mu$ moles of amino acid, $0.4 \mu$ moles of pyridoxal phosphate, $200 \mu$ moles of bicine buffer, $\mathrm{pH} 9.0$, and $2.0 \mu \mathrm{g}$ of the enzyme in a total volume of $4.0 \mathrm{ml}$.

\begin{tabular}{lc}
\hline \multicolumn{1}{c}{ Amino acid } & Relative rate \\
\hline L-Threonine & 100 \\
DL-Allothreonine & 0 \\
DL- $\alpha$-Aminobutyrate & 0 \\
L-Methionine & 0 \\
L-Serine & 17 \\
L-Phenylalanine & 0 \\
L-Histidine & 0 \\
L-Alanine & 0 \\
S-Methyl-L-cysteine & 0 \\
L-Homoserine & 0 \\
$\beta$-Cl-L-Alanine & 83 \\
\hline
\end{tabular}

$\beta$-chloro-L-alanine were degraded well, but not D-isomers of these amino acids. L-Serine showed approximately $17 \%$ reactivity in comparison with $\mathrm{L}$-threonine and $\beta$-chloro-L-ala- 
nine showed almost the same reactivity with L-threonine.

Activation by adenosine nucleotides. Effects of AMP, ADP and ATP on the enzyme activity were investigated, since the activation of biodegradative threonine deaminase by these nucleotides was reported by many workers. ${ }^{2,12,13 \text {, }}$ As shown in Table III, addition of AMP to

Table III. Activation of Biodegradative Threonine DeAMINASE BY AdENosine NucleótIDES

Assay system of pH 9.3 contained $10 \mu$ moles of L-threonine, $0.4 \mu$ mole of pyridoxal phosphate, 4 $\mu$ moles of AMP (ADP or ATP), $200 \mu$ moles of $\mathrm{NH}_{4} \mathrm{OH}-\mathrm{NH}_{4} \mathrm{Cl}$ buffer, $\mathrm{pH} 9.3$, and $1.0 \mu \mathrm{g}$ of the enzyme in a total volume of $4.0 \mathrm{ml}$. Assay system of pH 7.5 contained the same components in a total volume of $4.0 \mathrm{ml}$ except that $\mathrm{NH}_{4} \mathrm{OH}-\mathrm{NH}_{4} \mathrm{Cl}$ buffer was replaced with $200 \mu$ moles of potassium phosphate buffer, $\mathrm{pH} 7.5$.

\begin{tabular}{lcc}
\hline & \multicolumn{2}{c}{ Relative rate } \\
\cline { 2 - 3 } Addition & $\mathrm{pH} \mathrm{7.5}$ & $\mathrm{pH} \mathrm{9.3}$ \\
\hline None & $100^{a}$ & $100^{b}$ \\
AMP & 1,990 & 1,490 \\
ADP & 1,030 & 119 \\
ATP & 121 & 132 \\
\hline
\end{tabular}

a) $0.96 \mu$ mole and $b$ । $1.44 \mu$ moles of $\alpha$-ketobutyrate was formed for 20 min reaction, respectively.

the reaction mixture markedly stimulated the formation of $\alpha$-ketobutyrate from L-threonine by the enzyme at $\mathrm{pH} 7.5$ and 9.3 . The activation of enzyme was also observed by the addition of ADP, but only at $\mathrm{pH} 7.5$. It has no effect at $\mathrm{pH}$ 9.3. ATP did not show any activation effect at all. These activation by adenosine nucleotides strongly suggested that the enzyme from $P$. morganii was a so called biodegradative threonine deaminase. Reactivity of $\mathrm{L}$-serine and $\beta$-chloro-L-alanine was also stimulated in the presence of AMP around 10 to 15 -fold, respectively.

The Michaelis constants for L-threonine and L-serine were determined in the presence and absence of AMP. As shown in Table IV, they were found to be $24.0 \mathrm{~mm}$ and $30.3 \mathrm{~mm}$ for Lthreonine and L-serine, respectively, in the absence of AMP, and 1.5 and $8.9 \mathrm{mM}$ for $\mathrm{L}-$
Table IV. EFFect of AMP on the $K m$ Values FOR L-THREONINE AND L-SERINE

The enzyme activity was determined by the standard assay system.

\begin{tabular}{lcc}
\hline \multirow{2}{*}{ Substrate } & \multicolumn{2}{c}{$K m$ values (mM) } \\
\cline { 2 - 3 } & without AMP & with $1 \mathrm{mM}$ AMP \\
\hline L-Threonine & 24 & 1.5 \\
L-Serine & 30 & 8.9 \\
\hline
\end{tabular}

threonine and L-serine in the presence of AMP.

Optimum $p H$. Variation of enzyme activity with $\mathrm{pH}$ was determined with $\mathrm{L}$-threonine and L-serine. The optimum $\mathrm{pH}$ for these substrates was around 9.0 in the absence of AMP (Fig. 10). In the presence of $1 \mathrm{mM} \mathrm{AMP,} \mathrm{the}$

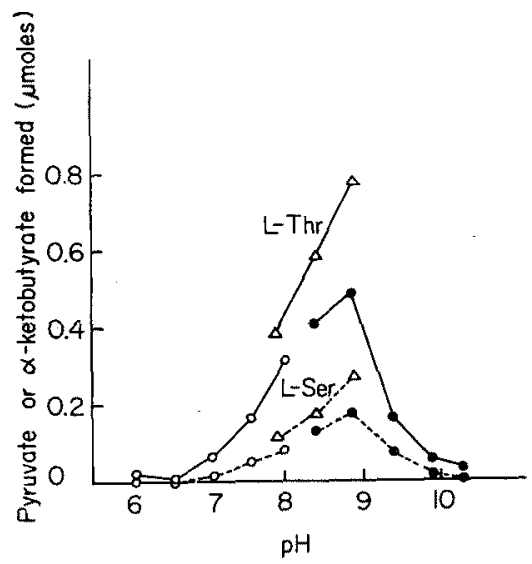

Fig. 10. Effect of pH on the Rate of Reaction of Biodegradative Threonine Deaminase.

The enzyme activities were determined using Lthreonine or L-serine as the substrate under the standard assay conditions except that 200 umoles of potassium phosphate buffer, between pH 6.0 and 8.0 (open circles) and $200 \mu$ moles of bicine buffer, between pH 8.0 and 9.0 (triangles) were employed in place of $\mathrm{NH}_{4} \mathrm{OH}-\mathrm{NH}_{4} \mathrm{Cl}$ buffer, which was used between $\mathrm{pH}$ 8.5 and 10.5 (closed circles). The enzyme, $2.3 \mu \mathrm{g}$ and $7.0 \mu \mathrm{g}$, was used for $\mathrm{L}$-threonine and for $\mathrm{L}$-serine degradation, respectively.

$\mathrm{pH}$ region at which the enzyme reacted optimally with L-threonine became much wider and it was found to be between 8.0 and 9.5 (Fig. 11).

Activator constant. Calculation of activator constants as performed at different substrate 


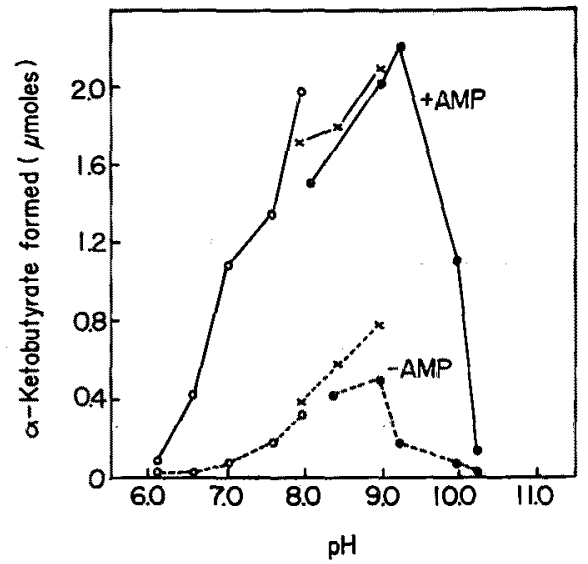

FIG. 11. Effect of $\mathrm{pH}$ on the Rate of Reaction of Biodegradative Threonine Deaminase in the Presence and Absence of AMP.

The conditions of determination of enzyme activities are the same as described in Fig. 10 except that the symbols $(x-x)$ shows bicine buffer between $\mathrm{pH} 8.0$ and 9.0. The enzyme, $1.8 \mu \mathrm{g}$ was used in the presence of $1 \mathrm{mM}$ AMP and $2.3 \mu \mathrm{g}$ was used in its absence. I-Threonine was used as the substrate.

concentrations by plotting the reciprocals of the concentrations of AMP. Table $\mathrm{V}$ shows the $K a$ values for AMP at different substrate concentrations. The value decreases as the substrate concentration increases.

TABle V. Dependency of Ka VALUes for AMP on l-Threonine Concentrations

The enzyme activities were determined under the standard assay system except that variable amounts of AMP were added to the reaction mixture.

\begin{tabular}{cc}
\hline L-Threonine (mM) & $K a$ values $(\mathrm{mM})$ \\
\hline 0.50 & 3.13 \\
1.25 & 1.12 \\
2.50 & 0.95 \\
5.00 & 0.55 \\
\hline
\end{tabular}

\section{DISCUSSION}

Proteus morganii showed markedly high threonine deamination activity in its cells when it grew in a medium containing high concentration of yeast extract. During the purification of the enzyme, the enzyme activity was divided into two parts by ammonium sulfate fractionation. These activities can be ascribed to different enzymes because they can also be separated by gel filtration with Sephadex G-200 and by hydroxylapatite column chromatography. ${ }^{3)}$ These two enzymes were purified separately and distinguished from each other. The purification and some properties of the biodegradative enzyme were described in this paper. The other enzyme, which is inhibited by L-isoleucine and should be a biosynthetic threonine deaminase, will be described elsewhere.

In $E$. coli, formation of the biodegradative threonine deaminase was observed only when the bacterium grew anaerobically in the medium containing high concentration of amino acids and no glucose. Formation of the biodegradative threonine deaminase by $P$. morganii was, however, observed under aerobic conditions. The biodegradative enzyme from $E$. coli was unstable and required AMP not only to show the maximum activity but also for stabilization and crystallization, ${ }^{13}$ ) while the enzyme from $P$. morganii was considerably stable even in the absence of AMP and it could be purified and crystallized in its absence, although it showed the maximum activity in the presence of AMP.

The molecular weight of the enzyme from $P$. morganii was approximately 120,000 and that of the subunit was about 32,000 , suggesting the enzyme to consist of 4 identical subunits. Taking into consideration this fact and according to the result of fluorometric analysis, the enzyme seems to contain 4 moles of pyridoxal phosphate per mole of enzyme protein. These properties were very similar to those of biodegradative threonine deaminase from $E$. coli. ${ }^{14)}$

Wood and Gunsalus ${ }^{2)}$ reported that biodegradative threonine deaminase from $E$. coli was activated by AMP and Hayaishi et $a l^{12 j}$ reported that the enzyme from Clostridium tetanomorphum was activated by ADP, while we found out that the enzyme from $P$. morganii was activated by both AMP and ADP.

The $K a$ value for AMP of the enzyme was found to be dependent on the concentration of L-threonine. It was $0.55 \mathrm{~mm}$ at threonine con- 
centration of $5.0 \mathrm{mM}$, whereas the $K a$ value for AMP of the enzyme from $E$. coli was reported to be $1.7 \mathrm{~mm}^{13)}$ and the $K a$ value for ADP of the enzyme from $C$. tetanomorphum was $0.006 \mathrm{~mm}^{15)}$ at the same threonine concentration of $5.0 \mathrm{~mm}$.

\section{REFERENCES}

1) H. E. Umbarger and B. Brown, J. Bacteriol., 73, $105(1957)$.

2) W. A. Wood and I. C. Gunsalus, J. Biol. Chem., 181, 171 (1949).

3) H. Kumagai, T. Nishimura, T. Ohsawa and $H$. Yamada, Amino Acid and Nucleic Acid (Japanese), 35, 123 (1977).

4) T. E. Friedemann and G. E. Haugen, I. Biol.
Chem., 147, 415 (1943).

5) K. Soda, Agric. Biol. Chem., 31, 1054 (1967).

6) A. Ehrenberg, Acta Chem. Scand., 11, 1257 (1957).

7) L. Ornstein, Ann. New York Acad. Sci, 121, 321 (1964).

8) B. J. Davis, ibid., 121, 404 (1964).

9) K. Weber and M. Osborn, J. Biol. Chem., 244, 4406 (1969).

10) E. Adams, Anal. Biochem., 31, 118 (1969).

11) D. E. Metzler, J. Am. Chem. Soc., 79, 485 (1957).

12) O. Hayaishi, M. Gefter and H. Weissbach, $J$. Biol. Chem., 238, 2040 (1963).

13) M. Hirata, M. Tokushige, A. Inagaki and $O$. Hayaishi, ibid., 240, 1711 (1965).

14) Y. Shizuta, A. Nakazawa, M. Tokushige and $O$. Hayaishi, ibid., 244, 1883 (1969).

15) A. Vanquickenborne and A. T. Phillips, ibid., 243, 1312 (1968). 